\title{
Pediatri Ünitelerinde Çalışan Hemşirelerin Duyarlı Sevgi Düzeyleri ile Merhamet Düzeyleri Arasındaki Ilişki
}

\author{
(1D) Elif Orhan ${ }^{1}$, (1D) Aysel Kökcü Doğan²
}

${ }^{1}$ Uzm. Hemşire, İstanbul Medipol Üniversitesi, Sağlık Bilimleri Fakültesi, Hemşirelik Anabilim Dalı, İstanbul, Türkiye.

${ }^{2}$ Dr. Öğr. Üyesi, İstanbul Medipol Üniversitesi, Sağlık Bilimleri Fakültesi, Hemşirelik Anabilim Dalı, İstanbul, Türkiye.

Öz

\section{Pediatri Ünitelerinde Çalıșan Hemșirelerin Duyarlı Sevgi Düzeyleri ile Merhamet Düzeyleri Arasındaki iliş̦ki}

Amaç: Araşıırma pediatri ünitelerinde çalışan hemşirelerin duyarlı sevgi düzeyleri ile merhamet düzeyleri arasındaki ilișkiyi belirlemek amacı ile yapılmıștır.

Gereç ve Yöntem: Araștırma, İstanbul ilinde bulunan beș özel ve iki devlet hastanesinin pediatri ünitelerinde gerçekleștirildi. Araștırmanın evrenini; pediatri ünitelerinde çalışan 350 hemşire, örneklemini ise araştırmaya katılmaya gönüllü toplam 278 hemşire oluşturdu. Veriler "Duyarlı Sevgi Ölçeği” ve "Merhamet Ölçeği” kullanılarak toplandı.

Bulgular: Araştırmaya katılan hemşirelerinin \%88.8'inin kadın, \%46’ıını 26-35 yaş aralığında, \%76.3'ünün lisans ve üzeri mezunu olduğu,

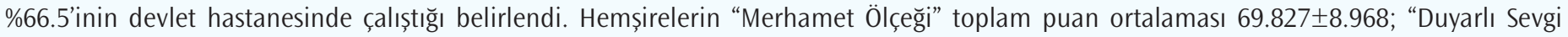
Ölçeği" toplam puan ortalaması ise $103.590 \pm 19.427$ bulundu. Araştırma grubundaki hemşirelerin Merhamet ölçeği toplam puanı ile tüm alt boyutlar arasında pozitif ilişki bulundu. Duyarlı Sevgi Ölçeği toplam puan ortalaması" ile "Merhamet Ölçeği Bağlantısızlık Alt Boyutu" arasında pozitif, "Sevecenlik Alt Boyutu" arasında ise negatif ilișki $(p<0.05)$ saptandı. Paylaşımların Bilincinde Olma Alt Boyutu ile görev süresi arasında, Bağlantısızlık Alt Boyutu ile Çalışılan Birim arasında, ilişki Kesme Alt Boyutu ile çalışılan kurum ve medeni durum arasında istatistiksel anlamlı farklılık saptandı $(\mathrm{p}<0.05)$.

Sonuç: Pediatri hemşirelerine hizmet içi eğitimler, öğrenci hemşirelere ise yenilenen müfredat programlarına eklenen merhametli bakım konuları ile "merhametli bakım" ve "duyarlı sevgi" kavramları benimsetilmeli, pediatri hemșirelerinde merhamet duygusu ve duyarlı sevgi geliştirilerek uygulamaya aktarılabilmelidir. Merhamet ve Duyarlı Sevgi ile ilgili kanıta dayalı çalışmaların farklı gruplarda ve farklı katılımcılarla yapılması önerilmektedir.

Anahtar Kelimeler: Merhamet, Duyarlı Sevgi, Pediatri, Hemşire

\section{Abstract}

Relationship Between Sensitive Love Levels and Compassions Levels of Nurses Those Work at Department of Pediatrics

Objective: This work is planned as being complementary in order to determine the relationship between sensitive love levels and compassions levels of nurses those work at department of pediatrics.

Methods: This research is done in 5 private and 2 public hospitals' departments of pediatrics in Istanbul City, between November 2019- March 2020. The population of this research consists of nurses of pediatrics while the sample group consists of 278 nurses who attended to this research voluntarily. Data is collected by using "Introductory Information Form", "Sensitive Love Scale" and "Compassions Scale". The data obtained in the study were analyzed using the SPSS (Statistical Package for Social Sciences) for Windows 22.0 program.

Results: It's determined that the profiles of the nurses those attended the research were as: $88.8 \%$ are women, $46 \%$ are in $26-35$ age range, $76.3 \%$ have bachelor and upper degrees, $66.5 \%$ work at public hospitals, The point average of the nurses for the Compassions Scale was determined as $69.827 \pm 8.968$ while their point average for the Sensitive Love Scale was determined as $103.590 \pm 19.427$.

Conclusion: The concepts of "compassionate care" and "sensitive love" should be adopted with in-service training for pediatric nurses, compassionate care subjects added to the renewed curriculum for student nurses, and a sense of compassion and sensitive love should be developed and transferred to practice in pediatric nurses. Evidence-based studies on Compassion and Sensitive Love are recommended to be conducted in different groups and with different participants.

Keywords: Compassions, Sensitive Love, Pediatrics, Nurse

Nasıl Atıf Yapmalı: Orhan E, Doğan AK. Pediatri Ünitelerinde Çalıșan Hemșirelerin Duyarlı Sevgi Düzeyleri ile Merhamet Düzeyleri Arasındaki ilișki. MKÜ Tip Dergisi. 2021;12(44):149-157. https://doi.org/10.17944/mkutfd.908807

Sorumlu Yazar/Corresponding Author: Uzm. Hemșire Elif Orhan 


\section{Giris}

Duyarlı sevgi fedakârlık, yardımseverlik, önemseme, ilgi, empati, sempati ve duyarlılık gibi özellikleri içerir. Duyarlı sevgi, bireylere destek sağlamaktadır. Duyarlı sevgi empati ile karıștırılmamalıdır. Empatiden farkı sürekli ve tüm insanlığı kapsamasıdır (1).

Merhamet duygusu, içselleștirilmiş bir duygu türüdür. Insanın özünde oluştuğu için merhamet geliștirilmeye açıktır. Merhamet, sadece tanıdıklarımıza değil tüm insanlara karșı gösterilebilmektedir. İnsanın, etrafındaki insanların sorunlarını gözlemlediğinde yardımseverliğe dönüşebilen bir davranıștır (2).

Hemșirelik, anne rahminden bașlayarak doğum sonu aldığımı ilk nefesten alacağımız son nefese kadar olan zaman diliminde hastaya el, yürek ve beyin ile bakım veren bir meslektir. Bireysel gereksinimlerini karșılayamayan bireye yardımı amaçlayan hemşirelik mesleği, hastalara karșı merhametli ve duyarlı sevgiye sahip hemșirelere ihtiyaç duyar. Bu nedenle hemşirelik mesleğinde yer alacak bireylerin merhamet ve duyarlı sevgi düzeyi, verilecek bakım kalitesi açısından önem taşımaktadır.

Duyarlı sevgi, yakınındaki bireylere, yabancıya veya insanlığa karșı duyulan ilgi, alaka, duyarlılık ve diğer bireyler acı çekerken ve yardıma ihtiyacı olduğunda destekleme, yardımcı olma ve diğer bireyleri anlamak için yoğunlașmıș duygu, düșünce ve davranıșları içeren bir tutumdur. Merhametli bakım kișisel özelliklerin yanında kültürel özelliklerde de etkilidir. Bireyin içinde bulunduğu kültürel değerler, bireyin düşünce, davranıș ve duygusunu etkilemektedir (3).

Hemşirelerin bakım vermesini kolaylaştıran, merhamet duygusu ve duyarlı sevgidir. Duyarlı sevgi hemșirelerde sosyal davranışın ortaya çıkmasını sağlamakta, bireylerin iyilik halini desteklemeye yardımcı olmakta ve kendilerine duyulan saygının artmasını sağlamaktadır. İnsanlar tarafından sevilmenin, insan kișiliğine katkısı önemlidir. Insanlara, olumlu duygu ve davranıșlar gösterildiğinde, kendi öz-saygılarına, iyilik hallerine ve uzun vadede toplumsal ilișkilerine olumlu yansımaları olacaktır (4).

Kaliteli ve güvenli hasta bakımı sağlanmalı, hasta ve hemșire memnuniyeti arttırılmalı, bunun yanında mesleki memnuniyetin devamını sağlamak için pediatri ünitelerinde çalıșan hemșirelere merhamet ve duyarlı sevgi konusunda eğitimler verilerek programlar olușturulmalıdır. Hemșireler duyarlı sevginin ve merhametin bilincinde olduğunda, bakım kalitesi yükselecek ve aynı zamanda hemșirelerin sosyal hayatlarını düzenlemelerine destek sağlayacaktır.

Literatürde, pediatri hemșirelerinin duyarlı sevgi düzeyleri ve merhamet düzeyleriyle ilișkili her iki parametrenin birlikte incelendiği bir araștırmaya rastlanılmamıștır. Pediatri hemși- relerinin merhamet ve duyarlı sevgi düzeylerinin bakım kalitesini etkilediği düşünülmektedir. Merhamet ve duyarlı sevgi düzeyinin çocuk hemşirelerinde meydana getirebileceği etkileri saptamanın ve çözüm önerileri geliștirmenin, hemşirelerin yaşam kalitesinin artmasına dolayısıyla pediatrik sağlık bakım kalitesinin gelișimine zemin hazırlayabileceği öngörülmektedir.

Bu bilgiler ışığında araştırma, pediatri ünitelerinde çalışan hemșirelerin merhamet düzeyleri ve duyarlı sevgi düzeyleri arasındaki ilişkiyi incelemek amacı ile yapılmıştır.

Bu amaç doğrultusunda araștırmada aşağıdaki sorulara da yanıt aranmıştır.

- Pediatri ünitelerinde çalıșan hemșirelerin duyarlı sevgi düzeyleri nedir?

- Pediatri ünitelerinde çalışan hemşirelerin merhamet düzeyleri nedir?

- Pediatri ünitelerinde çalışan hemşirelerin duyarlı sevgi düzeyleri ile merhamet düzeyleri arasında ilişki var midır?

\section{GEREC VE YÖNTEM}

\section{Araștırmanın Tipi}

Bu araştırma tanımlayıcı nitelikte, kesitsel bir araştırmadir.

\section{Araștırmanın Evreni ve Örneklemi}

Araștırmanın evrenini; İstanbul Medipol Üniversitesine bağlı beş özel ve iki devlet hastanesinin pediatri ünitelerinde çalıșan 350 hemșire olușturdu. Araștırmada örneklem seçimine gidilmemiş olup, araștırma yapılacak hastanelerin pediatri ünitelerinde çalıșan ve araștırmaya katılmaya gönüllü toplam 278 hemșire örneklem grubunu olușturdu. Katılımcıların 177'si devlet hastanesinde, 101'i ise özel hastanede çalışan hemșirelerdi. Evrenin \%79.42 'sine ulașıldı. Veriler 2020 OcakMart ayları arasında toplandı.

Verilerin Toplanması: Veriler "Tanıtıcı Bilgiler Formu", "Duyarlı Sevgi Ölçeği” ve "Merhamet Ölçeği" kullanılarak toplandı. Araștırmaya katılmaya gönüllü hemşirelere araștırma ve ölçekler hakkında gerekli açıklamalar yapılarak onamları alındı ve ölçekler uygulandı. Hemșireler tarafından anket için on dakikalık süre ayrıldı.

Tanıtıcı Bilgiler Formu; Araștırmacılar tarafından hazırlanan formda hemșirelerin cinsiyet, yaș, eğitim durumu, çalıştıkları kurum, tecrübe süresi, çalıștıkları birim, görev süresi, medeni durum ve çocuk sayısına ilişkin veriler yer aldı.

Merhamet Ölçeği; Pommier tarafından 2011 yılında geliştirildi. Ölçeğin Türkçe geçerlik ve güvenirlik çalıșması Akdeniz ve Deniz tarafından 2016 yılında yapıldı. Bu ölçek, ilişki 
kesme, bilinçli farkındalık, bağlantısızlık, paylașımların bilincinde olma, sevecenlik ve umursamazlık olmak üzere altı alt boyuttan olușmaktadır. Beșli likert tipi olan ölçekte 24 madde bulunmaktadır. Ölçeğin tümü için Cronbach Alfa iç tutarlılık güvenirlik katsayısı .85 olarak bulundu. Araștırmamızda kullanılan Merhamet ölçeğinin genel güvenilirliği alpha $=.92$ olarak bulundu. Ölçekten alınan toplam puan arttıkça merhamet düzeyinin arttığı varsayıldı.

Duyarlı Sevgi Ölçeği; Sprecher ve Fehr tarafından 2005 yıIında geliștirilen Duyarlı Sevgi Ölçeği, Akın ve Eker tarafından 2011 yılında Türkçeye uyarlandı. Ölçek 21 maddeden oluşmaktadır. Ölçeğin alt boyutları bulunmamaktadır. 7’li likert tipte bir ölçektir. Ölçeğin madde-toplam korelasyonlarının ise. 28 ile .70 arasında sıralandığı görülmüștür. Ölçeğin iç tutarlılık güvenirlik katsayısı 0.89 , test tekrar test güvenirlik katsayısı ise 0.82 olarak bulunmuștur. Araștırmamızda kullanılan Duyarlı Sevgi Ölçeğinin Cronbach Alfa kat sayısı .94 bulundu. Ölçekten alınan yüksek puanlar bireyin duyarlı sevgi düzeyinin yüksek olduğunu göstermektedir.

\section{Verilerin Analizi}

Araștırmada elde edilen veriler IBM SPSS Statistics (Statistical Package for Social Sciences) for Windows 22.0 programı kullanılarak analiz edildi. Verilerin değerlendirilmesinde tanımlayıcı istatistiksel yöntemleri olarak sayı, yüzde, ortalama, standart sapma kullanıldı. íki bağımsız grup arasında niceliksel sürekli verilerin karșılaștırılmasında t-testi, ikiden fazla bağımsız grup arasında niceliksel sürekli verilerin karşılaștırılmasında Tek yönlü (One way) Anova testi kullanıldı. Anova testi sonrasında farklılıkları belirlemek üzere tamamlayıcı post-hoc analizi olarak Scheffe testi kullanıldı. Araștırmanın sürekli değișkenleri arasında pearson korelasyon analizi uygulandı. Araștırma değișkenlerinin normal dağııım gösterip göstermediğini belirlemek üzere Kurtosis (Basıklık) ve Skewness (Çarpıklık) değerleri incelendi $(5,6)$. Merhamet Ölçeği Kurtosis (Basıklık) değeri 1.152, Skewness (Çarpıklık) değeri-0.974 incelendi. Duyarlı Sevgi Ölçeği Kurtosis (Basıklık) değeri 1.308, Skewness (Çarpıklık) değeri -0.74 incelendi.

\section{BULGULAR}

Bu bölümde, araștırma probleminin çözümü için, araștırmaya katılan hemşireler ölçekler yoluyla toplanan verilerin analizi sonucunda elde edilen bulgular yer almaktadır. Elde edilen bulgulara dayalı olarak açıklama ve yorumlar yapılmıștır.

Araștırmaya katılan hemșirelerin \%88.8'inin kadın, \%46'sının 26-35 yaș aralığında, \%76.3'ünün lisans ve üzeri mezunu olduğu belirlendi. Hemșirelerin \%66.5'inin devlet hastanesinde, \%33.5’inin özel hastanede çalıștığı, \%55.4'ünün 1-3 yıl çalışma deneyiminin olduğu, \%39.2'sinin pediatri servislerinde çalıștığı, \%59.7'sinin 1-5 yıl bulundukları ünitede çalıștığı saptandı. Hemșirelerin \%69.4'ünün bekar ve \%84.2'sinin ise çocuk sahibi olmadığı tespit edildi (Tablo 1).

Tablo 1. Hemşirelerin tanıtıc özellikleri ( $n=278)$

\begin{tabular}{|c|c|c|c|}
\hline & Gruplar & $n$ & $\%$ \\
\hline \multirow{2}{*}{ Cinsiyet } & Erkek & 31 & 11.2 \\
\hline & Kadın & 247 & 88.8 \\
\hline \multirow{3}{*}{ Yaș } & $18-25$ & 125 & 45.0 \\
\hline & $26-35$ & 128 & 46.0 \\
\hline & $36-45$ & 25 & 9.0 \\
\hline \multirow{3}{*}{ Eğitim Durumu } & Lise & 34 & 12.2 \\
\hline & Ön Lisans & 32 & 11.5 \\
\hline & Lisans ve Üzeri & 212 & 76.3 \\
\hline \multirow{2}{*}{ Çalıșılan Kurum } & Devlet Hastanesi & 185 & 66.5 \\
\hline & Özel Hastane & 93 & 33.5 \\
\hline \multirow{3}{*}{ Tecrübe } & 1-3yıl & 154 & 55.4 \\
\hline & $4-10 y ı 1$ & 85 & 30.6 \\
\hline & 11- Yıl ve Üzeri & 39 & 14.0 \\
\hline \multirow{4}{*}{ Birim } & Servis & 109 & 39.2 \\
\hline & Acil & 32 & 11.5 \\
\hline & Yoğun Bakım & 89 & 32.0 \\
\hline & Diğer & 48 & 17.3 \\
\hline \multirow{3}{*}{ Görev Süresi } & 1 Yıldan Az & 64 & 23.0 \\
\hline & $1-5 Y_{I}$ & 166 & 59.7 \\
\hline & 5 Yıl Üzeri & 48 & 17.3 \\
\hline \multirow{2}{*}{ Medeni Durum } & Evli & 85 & 30.6 \\
\hline & Bekar & 193 & 69.4 \\
\hline \multirow{2}{*}{ Çocuk Sayısı } & Yok & 234 & 84.2 \\
\hline & Var & 44 & 15.8 \\
\hline
\end{tabular}

Tanımlayıcı İstatistikler

Örneklem grubunda bulunan hemşirelerin "Duyarlı Sevgi Ölçeği” puan ortalaması $103.590 \pm 19.427$ bulundu. Hemșirelerin Merhamet Ölçeği "Sevecenlik" alt boyutu puan ortalaması 9.176 \pm 2.338 , "Umursamazlık" alt boyutu puan ortalaması 11.151 \pm 1.838 , "Paylaşımların Bilincinde Olma" alt boyutu puan ortalaması 12.072 \pm 2.310 , "Bağlantısızlık" alt boyutu puan ortalaması 13.784 \pm 2.428 , "Bilinçli Farkındalık" alt boyutu puan ortalaması 11.309 \pm 2.578 , "ilișki Kesme" alt boyutu puan ortalaması 12.335 \pm 2.282 , "Merhamet Ölçeği" toplam puan ortalaması $69.827 \pm 8.968$ olarak saptandı (Tablo 2).

İki bağımsız grup arasında niceliksel sürekli verilerin karşılaștırılmasında t-testi, ikiden fazla bağımsız grup arasında niceliksel sürekli verilerin karşılaştırılmasında Tek yönlü (One way) Anova testi kullanıldı. Anova testi sonrasında farklılıkları belirlemek üzere tamamlayıc post-hoc analizi 


\begin{tabular}{|c|c|c|c|c|}
\hline \multicolumn{2}{|c|}{ ölçek/Alt Boyutlar } & $0 \mathrm{rt} \pm \mathrm{Ss}$ & Min. & Max. \\
\hline Duyarlı Sevgi & Toplam & $\begin{array}{c}103.590 \pm \\
19.427\end{array}$ & 24.000 & 147.000 \\
\hline \multirow{7}{*}{$\begin{array}{l}\text { Merhamet } \\
\text { Ölçeği }\end{array}$} & Sevecenlik & $9.176 \pm 2.338$ & 4.000 & 20.000 \\
\hline & Umursamazlık & $11.151 \pm 1.838$ & 4.000 & 17.000 \\
\hline & $\begin{array}{l}\text { Paylașımların } \\
\text { bilincinde 0lma }\end{array}$ & $12.072 \pm 2.310$ & 4.000 & 20.000 \\
\hline & Bağlantısızlık & $13.784 \pm 2.428$ & 4.000 & 20.000 \\
\hline & Bilinçli Farkındalık & $11.309 \pm 2.578$ & 4.000 & 20.000 \\
\hline & İlișki Kesme & $12.335 \pm 2.282$ & 4.000 & 20.000 \\
\hline & Merhamet Toplam & $69.827 \pm 8.968$ & 24.000 & 106.000 \\
\hline
\end{tabular}

lașma durumu Tablo 4'te belirtildi. Örneklem grubunda yer alan pediatri hemşirelerinin Merhamet Ölçeği Paylaşımların Bilincinde Olma Alt Boyutu puanları ile görev süresi arasında istatistiksel anlamlı farklılık saptandı $(p=0.037<0.05)$. Görev süresi 1-5 yıl olan hemşirelerin Paylaşımların Bilincinde Olma Alt Boyutu puan ortalaması $(12.361 \pm 2.315)$ diğer gruplardan yüksek bulundu.

Hemșirelerin "Merhamet Ölçeği” Bağlantısızlık alt boyutu puanları ile çalıştıkları birimleri arasında anlamlı farklılık belirlendi $(p=0.001<0.05)$. Yoğun bakımda çalıșan hemșirelerin


sekti.

Araștırmaya katılan hemșirelerin "Merhamet Ölçeği" ilișki Kesme alt boyut puanları ile çalıșılan kurum ve medeni durum arasındaki fark istatistiksel olarak anlamlı idi $(p<0.05)$. Özel hastanede çalışan hemșirelerin ilișki kesme puan ortalamaları $(12.860 \pm 1.987)$ devlet hastanesinde çaIıșanlardan, bekar hemșirelerin ilișki kesme alt boyut puanları (12.534 \pm 2.363$)$ evli olan hemşirelerin puanlarından (11.882 \pm 2.026$)$ yüksek bulundu.

Hemşirelerin sevecenlik, umursamazlık, paylaşımların bilincinde olma, bağlantısızlık, bilinçli farkındalık, merhamet toplam puanları çalışılan kurum değişkenine göre anlamlı farklılık göstermedi $(p>0.05)$.

Merhamet Puanlarının Tanımlayıcı özelliklere göre farklı-

Hemşirelerin sevecenlik, umursamazlık, paylașımların bi-

Tablo 3. Merhamet ile duyarlı sevgi arasında korelasyon analizi

\begin{tabular}{|c|c|c|c|c|c|c|c|c|c|}
\hline & & Sevecenlik & Umursamazlık & $\begin{array}{l}\text { Paylașımların } \\
\text { Bilincinde 0Ima }\end{array}$ & Bağlantısızlık & $\begin{array}{c}\text { Bilinçli } \\
\text { Farkındalık }\end{array}$ & $\begin{array}{l}\text { ilisșki } \\
\text { Kesme }\end{array}$ & $\begin{array}{l}\text { Merhamet } \\
\text { Toplam }\end{array}$ & Duyarlı Sevgi \\
\hline \multirow{2}{*}{ Sevecenlik } & $r$ & 1.000 & & & & & & & \\
\hline & $p$ & 0.000 & & & & & & & \\
\hline \multirow{2}{*}{ Umursamazlık } & $r$ & $0.295^{* *}$ & 1.000 & & & & & & \\
\hline & $p$ & 0.000 & 0.000 & & & & & & \\
\hline \multirow{2}{*}{$\begin{array}{l}\text { Paylașımların } \\
\text { Bilincinde 0Ima }\end{array}$} & $r$ & $0.260^{* *}$ & $0.404^{* *}$ & 1.000 & & & & & \\
\hline & $p$ & 0.000 & 0.000 & 0.000 & & & & & \\
\hline \multirow{2}{*}{ Bağlantısızlık } & $r$ & $0.142^{*}$ & $0.424^{* *}$ & $0.433^{* *}$ & 1.000 & & & & \\
\hline & $p$ & 0.018 & 0.000 & 0.000 & 0.000 & & & & \\
\hline \multirow{2}{*}{ Bilinçli Farkındalık } & $r$ & $0.154^{*}$ & $0.222^{* *}$ & $0.284^{* *}$ & $0.352^{* *}$ & 1.000 & & & \\
\hline & $p$ & 0.010 & 0.000 & 0.000 & 0.000 & 0.000 & & & \\
\hline \multirow{2}{*}{ İlișki Kesme } & $r$ & $0.172 * *$ & $0.362^{* *}$ & $0.398^{* *}$ & $0.404^{* *}$ & $0.357^{* *}$ & 1.000 & & \\
\hline & $p$ & 0.004 & 0.000 & 0.000 & 0.000 & 0.000 & 0.000 & & \\
\hline \multirow{2}{*}{ Merhamet Toplam } & $r$ & $0.514^{* *}$ & $0.656^{* *}$ & $0.708^{* *}$ & $0.710 * *$ & $0.632^{* *}$ & $0.688 * *$ & 1.000 & \\
\hline & $p$ & 0.000 & 0.000 & 0.000 & 0.000 & 0.000 & 0.000 & 0.000 & \\
\hline \multirow{2}{*}{ Duyarlı Sevgi } & $r$ & $-0.263 * *$ & 0.089 & -0.082 & $0.226^{* *}$ & 0.098 & -0.001 & 0.018 & 1.000 \\
\hline & $p$ & 0.000 & 0.137 & 0.171 & 0.000 & 0.103 & 0.987 & 0.770 & 0.000 \\
\hline \multicolumn{10}{|l|}{${ }^{*}<0,05 ;{ }^{* *}<0,01$} \\
\hline \multicolumn{10}{|c|}{ Pearson Korelasyon Analizi } \\
\hline
\end{tabular}


Tablo 4. Merhamet puanlarının tanımlayıe özelliklere göre farkllassma durumu ( $n=278)$

\begin{tabular}{|c|c|c|c|c|c|c|c|c|c|}
\hline & Demografik Özellikler & $\mathrm{n}$ & Sevecenlik & Umursamazlık & $\begin{array}{l}\text { Paylasıımların } \\
\text { Bilincinde 01ma }\end{array}$ & Bağlantısızlık & Bilinçli Farkındalık & Illişki Kesme & Merhamet Toplam \\
\hline & & & $0 \mathrm{rt} \pm S S$ & $0 \mathrm{rt} \pm S S$ & $0 \mathrm{rt} \pm \mathrm{SS}$ & $0 \mathrm{rt} \pm S S$ & $0 \mathrm{rt} \pm \mathrm{sS}$ & $0 \mathrm{rt} \pm \mathrm{sS}$ & $0 \mathrm{rt} \pm S S$ \\
\hline \multirow{4}{*}{ Cinsiyet } & Erkek & 31 & $9.065 \pm 2.707$ & $11.226 \pm 2.012$ & $12.000 \pm 2.696$ & $13.387 \pm 2.629$ & $10.613 \pm 3.062$ & $12.516 \pm 2.839$ & $68.807 \pm 10.248$ \\
\hline & Kadın & 247 & $9.190 \pm 2.294$ & $11.142 \pm 1.819$ & $12.081 \pm 2.264$ & $13.834 \pm 2.403$ & $11.397 \pm 2.505$ & $12.312 \pm 2.208$ & $69.956 \pm 8.809$ \\
\hline & $t=$ & & -0.282 & 0.240 & -0.184 & -0.966 & -1.600 & 0.469 & -0.672 \\
\hline & $p=$ & & 0.778 & 0.811 & 0.854 & 0.335 & 0.111 & 0.639 & 0.502 \\
\hline \multirow{5}{*}{ Yaş } & $18-25$ & 125 & $9.136 \pm 2.142$ & $11.184 \pm 1.820$ & $12.096 \pm 2.142$ & $13.832 \pm 2.365$ & $11.344 \pm 2.427$ & $12.392 \pm 2.355$ & $69.984 \pm 8.524$ \\
\hline & $26-35$ & 128 & $9.086 \pm 2.541$ & $11.164 \pm 1.831$ & $12.148 \pm 2.395$ & $13.805 \pm 2.532$ & $11.328 \pm 2.851$ & $12.305 \pm 2.316$ & $69.836 \pm 9.554$ \\
\hline & $36-45$ & 25 & $9.840 \pm 2.173$ & $10.920 \pm 2.019$ & $11.560 \pm 2.694$ & $13.440 \pm 2.256$ & $11.040 \pm 1.791$ & $12.200 \pm 1.732$ & $69.000 \pm 8.302$ \\
\hline & $\mathrm{F}=$ & & 1.122 & 0.220 & 0.689 & 0.279 & 0.150 & 0.093 & 0.125 \\
\hline & $p=$ & & 0.327 & 0.803 & 0.503 & 0.757 & 0.861 & 0.911 & 0.883 \\
\hline \multirow{5}{*}{ Eğitim Durumu } & Lise & 34 & $9.294 \pm 2.658$ & $11.588 \pm 2.285$ & $12.059 \pm 2.881$ & $14.059 \pm 2.449$ & $10.853 \pm 2.851$ & $12.559 \pm 2.299$ & $70.412 \pm 10.085$ \\
\hline & Ön Lisans & 32 & $9.219 \pm 2.166$ & $10.813 \pm 2.023$ & $11.469 \pm 2.140$ & $13.250 \pm 2.016$ & $11.438 \pm 1.865$ & $12.531 \pm 2.272$ & $68.719 \pm 7.932$ \\
\hline & Lisans ve Üzeri & 212 & $9.151 \pm 2.319$ & $11.132 \pm 1.723$ & $12.165 \pm 2.230$ & $13.821 \pm 2.479$ & $11.363 \pm 2.628$ & $12.269 \pm 2.287$ & $69.901 \pm 8.955$ \\
\hline & $\mathrm{F}=$ & & 0.060 & 1.522 & 1.266 & 1.016 & 0.617 & 0.369 & 0.322 \\
\hline & $p=$ & & 0.941 & 0.220 & 0.284 & 0.363 & 0.540 & 0.692 & 0.725 \\
\hline \multirow{4}{*}{ Calıșılan Kurum } & Devlet Hastanesi & 185 & $9.022 \pm 2.272$ & $11.103 \pm 1.910$ & $12.124 \pm 2.320$ & $13.616 \pm 2.543$ & $11.243 \pm 2.621$ & $12.070 \pm 2.378$ & $69.178 \pm 9.389$ \\
\hline & Özel Hastane & 93 & $9.484 \pm 2.448$ & $11.247 \pm 1.692$ & $11.968 \pm 2.301$ & $14.118 \pm 2.156$ & $11.441 \pm 2.500$ & $12.860 \pm 1.987$ & $71.118 \pm 7.956$ \\
\hline & $\mathrm{t}=$ & & -1.559 & -0.618 & 0.532 & -1.632 & -0.602 & -2.756 & -1.708 \\
\hline & $\mathrm{p}=$ & & 0.120 & 0.537 & 0.595 & 0.104 & 0.547 & 0.006 & 0.089 \\
\hline \multirow{5}{*}{ Tecrübe } & $1-3 y ı l$ & 154 & $9.117 \pm 2.123$ & $11.260 \pm 1.825$ & $12.175 \pm 2.200$ & $13.916 \pm 2.306$ & $11.500 \pm 2.506$ & $12.533 \pm 2.396$ & $70.500 \pm 8.683$ \\
\hline & 4-10yil & 85 & $9.094 \pm 2.653$ & $10.953 \pm 1.675$ & $12.059 \pm 2.311$ & $13.624 \pm 2.596$ & $11.165 \pm 2.811$ & $12.024 \pm 2.082$ & $68.918 \pm 8.931$ \\
\hline & 11- Yıl ve Üzeri & 39 & $9.590 \pm 2.436$ & $11.154 \pm 2.207$ & $11.692 \pm 2.726$ & $13.615 \pm 2.551$ & $10.872 \pm 2.308$ & $12.231 \pm 2.206$ & $69.154 \pm 10.111$ \\
\hline & $\mathrm{F}=$ & & 0.710 & 0.762 & 0.680 & 0.504 & 1.117 & 1.414 & 0.980 \\
\hline & $\mathrm{p}=$ & & 0.492 & 0.468 & 0.507 & 0.605 & 0.329 & 0.245 & 0.376 \\
\hline \multirow{7}{*}{ Birim } & Servis & 109 & $9.202 \pm 2.552$ & $10.927 \pm 1.773$ & $12.055 \pm 2.244$ & $13.229 \pm 2.602$ & $11.073 \pm 2.429$ & $11.991 \pm 2.363$ & $68.477 \pm 9.341$ \\
\hline & Acil & 32 & $8.938 \pm 2.139$ & $11.625 \pm 2.420$ & $11.969 \pm 2.621$ & $13.281 \pm 2.261$ & $11.063 \pm 2.124$ & $12.344 \pm 2.418$ & $69.219 \pm 8.186$ \\
\hline & Yoğun Bakım & 89 & $9.292 \pm 2.112$ & $11.315 \pm 1.564$ & $12.371 \pm 2.298$ & $14.483 \pm 2.079$ & $11.461 \pm 2.954$ & $12.562 \pm 2.281$ & $71.483 \pm 8.724$ \\
\hline & Diğer & 48 & $9.063 \pm 2.409$ & $11.042 \pm 1.978$ & $11.625 \pm 2.256$ & $14.083 \pm 2.413$ & $11.729 \pm 2.430$ & $12.688 \pm 1.937$ & $70.229 \pm 8.772$ \\
\hline & $\mathrm{F}=$ & & 0.224 & 1.552 & 1.120 & 5.291 & 0.928 & 1.510 & 1.936 \\
\hline & $p=$ & & 0.879 & 0.201 & 0.341 & 0.001 & 0.428 & 0.212 & 0.124 \\
\hline & Posthoc= & & & & & $3>1.4>1.3>2(p<0.05)$ & & & \\
\hline \multirow{6}{*}{ Görev Süresi } & 1 Yıldan Az & 64 & $9.063 \pm 2.174$ & $11.047 \pm 1.704$ & $11.578 \pm 1.876$ & $13.734 \pm 2.546$ & $11.141 \pm 2.519$ & $12.422 \pm 2.376$ & $68.984 \pm 8.422$ \\
\hline & $1-5 \mathrm{Yll}$ & 166 & $9.066 \pm 2.297$ & $11.247 \pm 1.827$ & $12.361 \pm 2.315$ & $13.892 \pm 2.299$ & $11.554 \pm 2.630$ & $12.428 \pm 2.300$ & $70.548 \pm 8.742$ \\
\hline & 5 Yıl Üzeri & 48 & $9.708 \pm 2.649$ & $10.958 \pm 2.052$ & $11.729 \pm 2.680$ & $13.479 \pm 2.713$ & $10.688 \pm 2.398$ & $11.896 \pm 2.076$ & $68.458 \pm 10.291$ \\
\hline & $F=$ & & 1508 & 0.591 & 3.349 & 0.553 & 2.303 & 1.073 & 1.382 \\
\hline & $p=$ & & 0.223 & 0.554 & 0.037 & 0.576 & 0.102 & 0.343 & 0.253 \\
\hline & Posthoc= & & & & $2>1(p<0.05)$ & & & & \\
\hline \multirow{4}{*}{ Medeni Durum } & Evli & 85 & $9.400 \pm 2.560$ & $11.188 \pm 1.887$ & $12.200 \pm 2.449$ & $13.835 \pm 2.525$ & $11.071 \pm 2.497$ & $11.882 \pm 2.026$ & $69.577 \pm 9.562$ \\
\hline & Bekar & 193 & $9.078 \pm 2.234$ & $11.135 \pm 1.821$ & $12.016 \pm 2.251$ & $13.762 \pm 2.390$ & $11.415 \pm 2.613$ & $12.534 \pm 2.363$ & $69.938 \pm 8.717$ \\
\hline & $t=$ & & 1.059 & 0.223 & 0.613 & 0.233 & -1.025 & -2.208 & -0.309 \\
\hline & $p=$ & & 0.291 & 0.823 & 0.541 & 0.816 & 0.306 & 0.028 & 0.758 \\
\hline \multirow{4}{*}{ Çocuk Sayısı } & Yok & 234 & $9.073 \pm 2.190$ & $11.081 \pm 1.793$ & $12.043 \pm 2.267$ & $13.761 \pm 2.383$ & $11.350 \pm 2.597$ & $12.368 \pm 2.322$ & $69.675 \pm 8.586$ \\
\hline & Var & 44 & $9.727 \pm 2.976$ & $11.523 \pm 2.040$ & $12.227 \pm 2.551$ & $13.909 \pm 2.683$ & $11.091 \pm 2.495$ & $12.159 \pm 2.068$ & $70.636 \pm 10.857$ \\
\hline & $\mathrm{t}=$ & & -1.710 & -1.465 & -0.485 & -0.371 & 0.612 & 0.555 & -0.652 \\
\hline & $p=$ & & 0.170 & 0.144 & 0.628 & 0.711 & 0.541 & 0.579 & 0.515 \\
\hline
\end{tabular}


lincinde olma, bağlantısızlık, bilinçli farkındalık, ilișki kesme, merhamet toplam puanları tecrübe değişkenine göre anlamlı farklılık göstermedi.( $p>0.05)$.

\section{TARTIȘMA}

Duyarlı sevgi düzeyiyle ilgili yapılan araştırmalar ve literatür incelendiğinde hemșirelerin duyarlı sevgilerini ölçen herhangi bir araștırmaya ulașılamamıștır. Araștırma kapsamındaki hemşirelerin "Duyarlı Sevgi Ölçeği" puan ortalaması $103.590 \pm 19.427$ 'dir. Bu sonuç, pediatri ünitelerinde çalıșan hemșirelerin duyarlı sevgi düzeylerinin yüksek olduğunu göstermektedir. Bunun sebebinin örneklem grubunu daha çok kadınların oluşturması ve kadınların duygusal yapısının erkeklere göre daha hassas olmasından kaynaklandığı düșünülmektedir.

Örneklem grubundaki hemșirelerin Merhamet Ölçeği top-

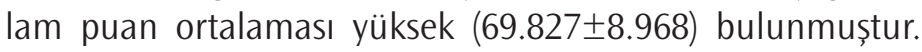
Çingöl tarafından yapılan hemșirelik bölümü öğrencilerinin merhamet düzeyleri ve merhamet düzeylerini etkileyen faktörlerin incelendiği çalıșmada, öğrencilerin merhamet ölçeği puan ortalaması $(4.19 \pm 0.44$ (max 5.0)) yüksek bulunmuștur. Ölçekten alınan puan arttıkça merhamet düzeyi de artmaktadır (7). Tanrıkulu tarafından yapılan çocuk kliniklerinde çalışan hemşirelerde merhamet düzeyi ve merhamet yorgunluğunun belirlenmesi çalışmasında, çalışan hemşirelerin merhamet ölçeği toplam puan ortalaması (98.55£11.44) çalıșmamızda olduğu gibi yüksek bulunmuștur (8).

Araștırma grubundaki hemșirelerin Merhamet ölçeği toplam puanı ile tüm alt boyutlar arasında pozitif ilișki bulunması hemşirelerin merhamet düzeylerinin yüksek olduğu anlamına gelmektedir. "Duyarlı Sevgi Ölçeği toplam puan ortalaması" ile "Merhamet Ölçeği Bağlantısızlık Alt Boyutu" arasında $(p<0.05)$ pozitif; Duyarlı sevgi ölçeği toplam puan ortalaması ile Merhamet ölçeği sevecenlik alt boyutu arasında ise $(p<0.05)$ negatif ilișki bulunmuștur.

Polat'ın yaptığı çalışmada; çalışmamızda olduğu gibi Merhamet Ölçeği paylașımların bilincinde olma alt boyutu ile sevecenlik boyutu arasında; bağlantısızlık alt boyutu ile umursamazlık alt boyutu arasında; bilinçli farkındalık alt boyutu ile sevecenlik alt boyutu ve paylașımların bilincinde olma alt boyutu arasında pozitif yönlü anlamlı ilișki $(p<0.05)$ olduğu tespit edilmiștir. Diğer taraftan çalıșmamızın aksine Polat çalışmasında, Merhamet Ölçeği sevecenlik alt boyutu ile umursamazlık alt boyutu arasında, paylașımların bilincinde olma alt boyutu ile umursamazlık alt boyutu arasında; bağlantısızlık alt boyutu ile sevecenlik alt boyutu arasında; ilişki kesme alt boyutu ile sevecenlik alt boyutu arasında; bilinçli farkındalık alt boyutu ile bağlantısızlık ve umursamazlık alt boyutu arasında negatif yönlü anlamlı ilișki $(p<0.05)$ bulurken, bağlantısızlık alt boyutu ile paylaşımların bilincinde olma alt boyutu arasında ise ilișkisi saptamamıștır (9).
Bağcıvan tarafından yapılan çalıșmada Merhamet Ölçeği sevecenlik alt boyutu ile umursamazlık alt boyutu arasında; paylașımların bilincinde olma alt boyutu ile umursamazlık alt boyutu arasında; paylașımların bilincinde alt boyutu ile bağlantısızlık alt boyutu arasında pozitif yönlü anlamlı ilișki $(p<0.05)$ saptanmıştır (10). Bağcıvan'ın çalıșmasında elde ettiği sonuçlar çalıșmamızla paralellik göstermektedir.

Tanrıkulu'nun Merhamet Ölçeği toplam puanları ile sevecenlik, paylaşımların bilincinde olma ve bilinçli farkındalık alt boyutları arasında pozitif anlamlı ilișki $(p<0.05)$ bulduğu çalıșma sonuçları çalıșmamızı destekler niteliktedir. TanrıkuIu çalışmamızın aksine Merhamet Ölçeği toplam puanları ile bağlantısızlık ve ilișki kesme alt boyut puanları arasında negatif yönlü anlamlı ilișki ( $p<0.05)$ saptamıștır (8).

Duyarlı sevgi ölçeği toplam boyutu ile sevecenlik alt boyutu arasında negatif, bağlantısızlık alt boyutu arasında ise pozitif ilișki bulunmuștur. Literatür taramalarında hemșirelik ve merhamet düzeyleri ile ilgili birçok alanda çalıșmaların yapıldı ̌̆ı, hemșirelerin merhamet düzeylerinin yüksek olduğu görülmüştür. Hemşirelik ve duyarlı sevgi alanında çalışmaların yapılmadığı saptanmıștır.

Araștırma grubunda yer alan hemşirelerin çalıştıkları kurum ile Merhamet Ölçeği iliş̦i kesme alt boyutu puanları arasında istatistiksel anlamlı farklılık $(p<0.05)$ saptanmıștır. Özel hastanede çalışan hemşirelerin ilişki kesme puanları devlet hastanesinde çalıșanlardan yüksektir. Bunun sebebi özel hastanelerin ağır çalıșma koșulları, fazla mesailer, izinli gün sayılarının az olması, ücretlerinin az olması ve devlete atanma durumlarının olması gösterilebilmektedir.

Örneklem grubunda yer alan hemșirelerin çalıștıkları birim ile Merhamet Ölçeği Bağlantısızlık alt boyut puanları arasında istatistiksel anlamlı farklılık $(p<0.05)$ belirlenmiștir. Farkın nedeni Birimi Yoğun Bakım olanların puanlarının diğer grupların puanlarından yüksek olmasıdır. Tanrıkulu'nun çalıșmasına baktığımızda aktif çalışılan üniteye göre yoğun bakım ve diğer servislerde çalışan hemşirelere ait merhamet yorgunluğu alt ölçek puan ortalaması acil servis, cerrahi servisi ve diğer servislerde çalıșan hemșirelerden daha düșük bulunmuștur (8). Acil serviste çalıșan hemșirelerin merhamet puanlarının yüksek olmasının sebebinin kaza, kayıp, ölüm vb. beklenmedik bir anda kriz yașayan çocuk ve ailelere hizmet vermekten kaynaklandığı düșünülmektedir. Branch ve ark. tarafından yapılan çalışmada pediatrik yoğun bakımda çalıșan hemşirelerin merhamet düzeyinin düşük, tükenmişlik ve stres düzeyinin yüksek olduğu bildirilmiștir (11). Berger yaptığı araştırmada, sağı ık çalışanlarının oluşturduğu 139 kişilik örneklem grubunun \%72'sinin merhamet yorgunluğu olduğunu bildirmiștir. Berger, yenidoğan yoğun bakım, onkoIoji servisi ve yoğun bakım birimlerinde çalıșan hemșirelerin merhamet yorgunluklarının daha fazla olduğunu bildirmiștir (15). 
Araștırmaya katılan hemșirelerin görev süreleri ile Merhamet Ölçeği Paylașımların Bilincinde Olma Alt Boyut puanları arasında istatistiksel anlamlı farklılık $(p<0.05)$ bulunmuștur. Farkın nedeni Görev süresi 1-5 yıl olanların paylaşımların bilincinde olma puanlarının diğer grupların puanlarından yüksek olmasıdır. Paylaşımların bilincinde olma, insanların mükemmel olmadığının ve hata yapabileceğinin bilincinde olmayı ifade ettiğinden görev süresi arttıkça kazanılması beklenmektedir. Hemşirelerin merhamet yorgunluğunu değerlendiren Polat tarafından yapılan çalıșmada, birimlerindeki hizmet süresi 1-5 yıl olanların, hizmet süresi 6-10 yıl olanlara göre sevecenlik puanının daha yüksek olduğu, hemșirelerin beș yıllık birim çalıșma süresinden sonra çalıșma heyecanlarını kaybetmiş olabilecekleri ifade edilmiștir (9). Araștırmada, birimlerinde 1 yıldan fazla çalıșan hemșirelerin sevecenlik davranıșının daha fazla görülmesi, hemşirelerin merhamet yorgunluğu olmadığını düșündürmektedir. Bağcıvan tarafından yapılan araștırmada, birimde 4-6 yıl çalıșma süresi olan çocuk hemșirelerinin sevecenlik, üç yıl ve daha az çalıșma süresi olanlarda umursamazlık alt boyutunun önemli düzeyde yüksek olduğu bulunmuștur (10). Taycan ve ark. tarafından yapılan çalışmada, çalıșma yılı ve kıdem arttıkça bașarının da arttığı sonucuna ulașılmıștır. Yeni ișe bașlayanların yaşadığı stresin daha çok öne çıktığı ve merhamet ortalamalarının yüksek olduğu bulunmuștur. Hemșirelerin kıdemi yükseldikçe mesleğini sevdiği, özümsediği düșünülmektedir (13). Jakimowicz ve ark. tarafından mesleki tecrübesi on beș seneden fazla olan hemşirelerin merhamet ve merhamet yorgunluğu puanlarının yüksek olduğu bildirilmiștir. Berger ve ark., yapmış olduğu 239 sağlık çalışanının katıldığı bir çalıșmada, mesleki tecrübesi 5 yıldan az olan hemșirelerin merhamet yorgunluğu yașadığı sonucuna ulașmıștır (14). Berger ve ark. tecrübeli hemșirelerin yașadıkları olumsuzluklara karșı farklı çözüm yolları geliștirmiş olabildikleri için merhamet düzeylerinin yüksek olabileceğini belirtmiștir. Bu veriler sonucunda pediatri hemșirelerinin mesleki tecrübelerinin artıkça iș doyumunun da arttığı ve ișini severek yaptığı düșünülmektedir (15). Koca'nın, yapmış olduğu çalıșmada ise meslekte deneyim arttıkça ve sürekli aynı bölümde çalıştıkça merhamet yorgunluğunun artırdığı belirtilmiștir (16).

Araştırmaya katılan hemşirelerin "Merhamet Ölçeği” iliş̧i Kesme alt boyut puanları ile çalıșılan kurum ve medeni durum arasındaki fark istatistiksel olarak anlamlı $(p<0.05)$ bulunmuștur. Özel hastanede çalıșan hemșirelerin ilișki kesme puanları devlet hastanesinde çalıșanların puanlarından yüksektir. Özel hastanenin çalıșma koşulları, sunduğu imkanlara bakıldığında ve hemșirelerin atanma durumları göz önünde bulundurulduğunda ilișki kesmesi normal karșılanmalıdır. Evli hemșirelerin ilișki kesme alt boyut puanları, bekarların ilișki kesme puanlarından düşük belirlenmiștir. Evli hemșirelerin aile düzenini ve aile birliğini koruma açısından çalıștığı kurumda kalması düșünülebilir. Bekar hemșirelerin ilișki kesme düzeyinin yüksek olması daha iyi çalıșma koșullarını hedeflemesi, ağır çalıșma șartlarının düzenini etkilememesi düșülmektedir. Scco ve arkadașları tarafından yapılan çalıșmada, yoğun bakım ünitesinde görevli hemșireler arasında, merhamet yorgunluğu alt boyutu puanlarının bekâr olan hemşirelerde daha yüksek düzeyde olduğu bulunmuştur (17). Yapılan bu çalıșmalar ve literatür bilgileri araștırmamızı destekler niteliktedir.

Duyarlı sevgi ölçeği ile tanıtıcı faktörler arasında ilișki buIunamamıștır. Ölçeğin geçerlik ve güvenirlik çalıșmalarından elde edilen bulgulara göre, ölçeğin kullanıma hazır olduğu söylenebilmektedir. Geçerlik ve güvenirliği için farklı gruplar üzerinde yapılacak çalıșmalar önemli bulunmaktadır. Duyarlı sevgi ölçeğinin kullanılacağı araştırmaların yapılması ölçme gücüne önemli katkılar sağlayacaktır (18). Sprecher ve Fehr tarafından insanlara yardım etmenin, sosyal destek vermenin empati ve duyarlı sevgiyle olan ilișkisinin araștırıldığı çalıșmada, empati ve duyarlı sevginin birbirinden bağımsız kavramlar olduğu bulunmuștur. İnsanların birbirleriyle yakın ilișkilerindeki sosyal destekle pozitif olarak duyarlı sevginin de arttığı gösterilmiștir $(19,20)$

\section{Araștırmanın Sınırlılıkları}

Araștırma, İstanbul Medipol Üniversitesine ait 5 özel hastane ve iki devlet hastanesinin pediatri ünitelerinde görev yapan çalıșmaya katılmaya gönüllü hemşireler ile sınırlı olup, elde edilen veriler kișisel bilgiye dayalıdır.

\section{SONUC}

Araștırmaya katılan hemșirelerin çoğunluğunun; kadın olduğu, 26-35 yaș aralı̆̆ında, lisans ve üzeri mezun olduğu, devlet hastanesinde çalıștı̆̆ı, 1-3 yıl iș deneyimi olduğu, pediatri servisinde çalıştıkları, 1-5 yıl aynı serviste çalıștıkları, bekâr ve çocuk sahibi olmadığı belirlendi.

Araștırma grubundaki hemșirelerin Merhamet ölçeği toplam puanı ile tüm alt boyutlar arasında pozitif yönlü yüksek düzeyde ilișki olduğu bulundu. Duyarlı Sevgi Ölçeği toplam puan ortalaması" ile "Merhamet Ölçeği Bağlantısızlık Alt Boyutu" arasında pozitif yönde yüksek, "Sevecenlik Alt Boyutu" arasında ise negatif yönde düşük düzeyde ilișki $(p<0.05)$ saptandı. Hemşirelerin "Merhamet Ölçeği" Paylașımların Bilincinde Olma Alt Boyutu puanları ile görev süresi arasında, Bağlantısızılık Alt Boyut puanları ile Çalıșılan Birim arasında, Ilișki Kesme Alt Boyut puanları ile çalıșılan kurum ve medeni durum arasında istatistiksel anlamlı farklılık saptandı.

Hemșirelerin merhamet düzeyleri ve duyarlı sevgi düzeylerinin arttırılması için yapılacak girișimler; hemșirelerin kișisel, çalıșma ve mesleki özelliklerine göre belirlenmelidir.

Pediatri ünitelerinde çalıșan hemşirelere hizmet içi eğitimler verilerek iletișim becerileri, stresle baș etme yöntemleri güçlendirilmeli, merhamet düzeyi farkındalığının artırılması 
sağlanmalıdır. Merhamet düzeyleri ve duyarlı sevgi düzeyleri açısından riskli bölümler belirlenerek, mesleki deneyimi yüksek yaș grupları bu riskli bölümlerde çalıștırılmalıdır. Pediatri hemșirelerine hizmet içi eğitimler, öğrenci hemșirelere ise yenilenen müfredat programlarına eklenen merhametli bakım konuları ile "merhametli bakım" ve "duyarlı sevgi" kavramları benimsetilmeli, pediatri hemșirelerinde merhamet duygusu ve duyarlı sevgi geliștirilmeli ve uygulamaya aktarılabilmelidir. Merhamet ve Duyarlı Sevgi ile ilgili kanıta dayalı çalıșmaların farklı gruplarda ve farklı katılımcılarla yapılması önerilmektedir.

\section{BILDIRIMLER}

Bu çalıșma, Elif Orhan isimli yazarın 2021 tarihli, "Pediatri Ünitelerinde Calışan Hemșirelerin Duyarlı Sevgi Düzeyleri ile Merhamet Düzeyleri Arasındaki ílișki” bașlıklı Yüksek Lisans Tezinin yeniden düzenlenmesi ile olușturulmuștur.

Değerlendirme

Dıș danıșmanlarca değerlendirilmiștir.

Cıkar Catıșması

Yazarlar bu makale ile ilgili herhangi bir çıkar çatıșması

bildirmemișlerdir.

Finansal Destek

Yazarlar bu çalıșma sırasında herhangi bir finansal destek kullanmamışlardır.

Etik Beyan

Bu çalıșma için İstanbul Medipol Üniversitesi Girișimsel Olmayan Klinik Araștırmalar Etik Kurulundan Kasım 2019 Mart 2020 tarih ve 10840098-604.01.01-E.53839 sayılı yazı ile izin alınmıș olup Helsinki Bildirgesi kriterleri göz önünde bulundurulmustur.

Yazar Katkısı

E.O, A.K.D., çalıșmanın kavramsallaștırılmasına ve tasarımına eşit derecede katkıda bulunmuştur. Veriler E.O. tarafından toplanmıștır.

\section{KAYNAKLAR}

1. Batson, C. D., Eklund, J. H., Chermok, V. L., Hoyt, J. L., \& Ortiz, B. G. An additional antecedent of empathic concern: Valuing the welfare of the person in need. Journal of Personality and Social Psychology, 2007:93;65-74. https://doi. org/10.1037/0022-3514.93.1.65

2. Avșaroğlu, S., ve Güleș, E. Özel gereksinimli çocuğa sahip anne babaların yaşam doyumlarının özanlayıș ve merhamet düzeyleri açısından incelenmesi. Kastamonu Eğitim Dergisi, 2019:27(1);365-376. https://doi.org/10.24106/kefdergi.2960

3. Şirin M, Yurttaş A. Hemșirelik bakımının bedeli: merhamet yorgunluğu. DEUHFED: 2015:123-130.

4. Bramley L., Matiti M. How Does It Really Feel to be in My Shoes Patients' Experiences of Compassion with in Nursing Care and Their Perceptions of Developing Compassionate Nurses Journal of Clinical Nursing, 2014:23;2790- 2799. https://doi. org/10.1111/jocn.12537
5. Tabachnick and Fidell, B.G. Tabachnick, L.S. Fidell Using Multivariate Statistics (sixth ed.) Pearson, Boston (2013).

6. George, D., Mallery, M. SPSS for Windows Step by Step: A Simple Guide and Reference, 17.0 update (10’a ed.) Boston: Pearson. (2010).

7. Çingöl N. Hemşirelik Bölümü Öğrencilerinin Merhamet Düzeyleri ve Merhamet Düzeylerini Etkileyen Faktörler. Klinik Psikiyatri, 2018;21:61-67.

8. Tanrıkulu G. Çocuk Kliniklerinde Çalışan Hemşirelerde Merhamet Düzeyi ve Merhamet Yorgunluğunun Belirlenmesi. Sağlık Bilimleri Enstitüsü, Hemşirelik Anabilim Dalı, Yüksek Lisans Tezi, Konya: Necmettin Erbakan Üniversitesi, (2019). https://doi.org/10.34108/eujhs.727445

9. Polat FN. Merhamet Yorgunluğu Düzeyinin Çalıșma Yașam Kalitesi ile Iliş̧isi: Sağılı Profesyonelleri Örneği. Sosyal Bilimler Enstitüsü, Sağlık Yönetimi Anabilim Dalı, Yüksek Lisans Tezi, Isparta: Süleyman Demirel Üniversitesi, (2016).

10. Bağcıvan E. Çocuk Hemșirelerinde Merhamet Yorgunluğunun Mesleki Yaşam Kalitesi ile illișkisi.Sağlık Bilimleri Enstitüsü, Çocuk Sağlığı ve Hastalıkları Hemșireliği Anabilim Dalı, Yüksek Lisans Tezi, Erzurum: Atatürk Üniversitesi, (2019).

11. Branch K, Klinkenberg D. Compassion Fatigue Among Pediatric Healthcare Providers. MCN, The American Journal of Maternal/Child Nursing;2015:40(3):160-166 https://doi. org/10.1097/NMC.0000000000000133

12. Branch C. Compassion Fatigue: Prevalence Among Nurses t A Midwest Pediatric Hospital, Dissertations. The Graduate School at the University of Missouri-St Louis In Partial Fulfillment of the Requirements for the degree of Doctor of Nursing Practice. (2013).

13. Taycan O, Kutlu L, Çimen S, Aydın N. Bir üniversite hastanesinde çalışan hemşirelerde depresyon ve tükenmişlik düzeyinin sosyo demografik değişkenlerle ilișkisi. Anatolian Journal of Psychiatry, 2006:6;100-108

14. Jakimowicz S, Perry L, Lewis J. Compassion satisfaction and fatigue: A cross- sectional survey of Australian intensive care nurses. Aust Crit Care,2018:31: 396405. https://doi. org/10.1016/j.aucc.2017.12.002

15. Berger J, Polivka B, Smooth EA, Oweens H. Compassions Fatigue In Pediatric Nurses. Journal of Pediatric Nursing. 2015(6):11-7. https://doi.org/10.1016/j.pedn.2015.02.005

16. Koca F, Hemşirelerde Merhamet Yorgunluğu ve Etkili Faktörlerin İncelenmesi. Maltepe Üniversitesi Să̆lık Bilimleri Enstitüsü, Cerrahi Hastalıkları Hemşireliği, Yüksek Lisans Tezi, İstanbul, (2018).

17. Sacco TL, Ciurzynski SM, Harvey ME, Ingersoll GL. Compassion satisfaction and compassion fatigue among critical care nurses. Critical Care Nurse, 2015:35: 32- 44. https://doi. org/10.4037/ccn2015392 
18. Akın, A. ve Eker, H. Duyarlı Sevgi Ölçeği: Geçerlik ve güvenirlik çalışması. Uludağ Üniversitesi Eğitim Fakültesi Dergisi, 2012:25(1), 75-85.

19. Underwood, L. G. Compassionate love: A frame-work for research. In B. Fehr, S. Sprecher, \& L. G. Underwood (Eds.), The science of compassionate love: Theory, research, and applications (s. 3-26). Malden, MA: (2009). Wiley-Blackwell.
20. Sprecher, S. and Fehr, B. Enhancement of mood and selfesteem as a result of giving and receiving compassionate love. Current Research in Social Psychology, 2006:11;227-242

21. Akdeniz S, Deniz ME. Merhamet Ölçeği'nin Türkçeye uyarlanması: Geçerlik ve güvenirlik çalışması. The Journal of Happiness \& Well-Being, 2016:4;50-61. 